\title{
Postnatal Iron Supplementation with Ferrous Sulfate vs. Ferrous Bis-Glycinate Chelate: Effects on Iron Metabolism, Growth, and Central Nervous System Development in Sprague Dawley Rat Pups
}

\author{
Shasta McMillen (1) and Bo Lönnerdal *
}

check for updates

Citation: McMillen, S.; Lönnerdal, B. Postnatal Iron Supplementation with Ferrous Sulfate vs. Ferrous

Bis-Glycinate Chelate: Effects on Iron Metabolism, Growth, and Central Nervous System Development in Sprague Dawley Rat Pups. Nutrients 2021, 13, 1406. https://doi.org/ 10.3390/nu13051406

Academic Editor: James H. Swain

Received: 16 March 2021

Accepted: 20 April 2021

Published: 22 April 2021

Publisher's Note: MDPI stays neutral with regard to jurisdictional claims in published maps and institutional affiliations.

Copyright: (c) 2021 by the authors. Licensee MDPI, Basel, Switzerland. This article is an open access article distributed under the terms and conditions of the Creative Commons Attribution (CC BY) license (https:/ / creativecommons.org/licenses/by/ $4.0 /)$.
Department of Nutrition, University of California, Davis, CA 95616, USA; samcmillen@ucdavis.edu

* Correspondence: bllonnerdal@ucdavis.edu; Tel.: +1-530-752-8347

\begin{abstract}
Iron-fortified formulas and iron drops (both usually ferrous sulfate, FS) prevent early life iron deficiency, but may delay growth and adversely affect neurodevelopment by providing excess iron. We used a rat pup model to investigate iron status, growth, and development outcomes following daily iron supplementation (10 $\mathrm{mg}$ iron $/ \mathrm{kg}$ body weight, representative of iron-fortified formula levels) with FS or an alternative, bioavailable form of iron, ferrous bis-glycinate chelate (FC). On postnatal day (PD) 2, sex-matched rat litters ( $n=3$ litters, 10 pups each) were randomly assigned to receive FS, FC, or vehicle control until PD 14. On PD 15, we evaluated systemic iron regulation and CNS mineral interactions and we interrogated iron loading outcomes in the hippocampus, in search of mechanisms by which iron may influence neurodevelopment. Body iron stores were elevated substantially in iron-supplemented pups. All pups gained weight normally, but brain size on PD 15 was dependent on iron source. This may have been associated with reduced hippocampal oxidative stress but was not associated with CNS mineral interactions, iron regulation, or myelination, as these were unchanged with iron supplementation. Additional studies are warranted to investigate iron form effects on neurodevelopment so that iron recommendations can be optimized for all infants.
\end{abstract}

Keywords: iron supplementation; ferrous bis-glycinate; ferrous sulfate; brain; infant nutrition

\section{Introduction}

Postnatal iron deficiency (ID) adversely affects both physical and cognitive development and should be prevented [1-5]. The American Academy of Pediatrics recommends infants receive iron through liquid supplements or fortified formula to prevent ID [6]. Iron-fortified formulas prevent postnatal ID effectively but provide, on average, 20 times the adequate intake (AI) for infants 0-6 months of age [7,8]. Excess iron can also be harmful to infants, and recent studies report adverse effects of iron supplementation in infants who are not ID [9-14]. In response to rising concern regarding the efficacy of blanket iron supplementation in infants, pediatric nutrition researchers as well as expert committees have recommended reevaluation of iron recommendations and stressed the need for postnatal iron supplementation research to identify adverse outcomes and define their biological mechanisms [15-22].

Previous studies on infants have reported reduced growth and deleterious cognitive outcomes due to iron supplementation [9-14]. In a randomized controlled trial (RCT), iron-sufficient infants who had received standard iron formula $(12.7 \mathrm{mg}$ iron/L) had poorer cognitive outcomes at 10 and 16 years of age $[10,11]$ compared to those who had received low-iron formula $(2.3 \mathrm{mg}$ iron/L). Comparable cognitive effects were observed in both rodents and pigs [23-26]. In these studies, several biological mechanisms may have contributed to the cognitive outcomes, including but not limited to iron under-regulation, iron-mineral interactions, or CNS iron overload-induced oxidative stress. 
Iron can compete with other essential trace minerals for absorption and transport and iron loading causes oxidative stress in biological environments through generation of reactive oxygen species (ROS). Systemic and cellular regulators of iron homeostasis work to ensure that the diverse iron needs of all tissues are met and still prevent iron toxicity. In early development, however, iron homeostasis might not be as responsive to elevated body iron stores. Indeed, postnatal iron supplementation increases body iron stores even in iron-replete infants [8,27], and under-regulation of iron metabolism in early life is further supported by postnatal iron regulation studies in humans [28], rats [29,30], mice [31], and piglets [25]. It is possible that under-regulation of iron homeostasis would permit iron overload in the CNS with increased iron intake, and iron uptake in the CNS may also be under-regulated postnatally, as previously indicated in rats [30]. Dysregulation of iron metabolism and iron loading contribute to neurodegeneration by causing oxidative stress $[32,33]$. Removal of iron from the CNS through iron chelation may even be a promising new therapy for those suffering cognitive effects of neurodegeneration [34]. Studies in rodents have concluded that neonatal iron exposure can promote neurodegenerative disease progression later in life, and this may be a result of neonatal CNS oxidative stress [19,24,26,35-37]. In neonatal pigs, increased iron supplementation led to iron loading in the hippocampus, the region that forms memories, as well as markers of lipid peroxidation (a form of oxidative stress), and impaired social behavior after weaning [25]. It was concluded that iron loading in the hippocampus might disrupt cognitive development directly through oxidative stress injury. Cognitive effects of iron supplementation have also been associated with reduced expression of myelin basic protein (MBP) in the hippocampus [38]. In summary, due to under-regulation of iron in early life, postnatal iron supplementation might lead to iron loading, and in the CNS, this could lead to oxidative stress and disrupt myelination, thereby explaining deficits in cognitive development.

The existence of a causal link between early life CNS iron exposure and neurodegenerative disease can only be speculated, but this possibility only highlights the need to study the effects of postnatal iron supplementation [19]. Previous studies in animals have relied on a range of iron intervention designs, but none have closely modeled routine postnatal interventions nor have they accounted for differences in milk iron intake between humans and model species [23,25,35,38,39]. Moreover, the vast majority all studies reporting adverse neurodevelopment effects of iron supplementation in humans have used ferrous sulfate (FS), whereas alternative chemical forms of iron have rarely been explored. Therefore, in addition to FS, we investigated the effects of ferrous bis-glycinate (FC), an amino acid chelated form of iron, which due to its unique absorptive fate may be less likely to cause the adverse effects attributed to FS [40]. FC has been shown to be effective and safe for use in infants as a bioavailable source of iron [41]. Herein, we characterized FS and FC iron supplementation effects on growth, iron status, iron regulation, and neurodevelopment in healthy, nursing rat litters, providing new insight into the activities of exogenous iron during one of the critical windows of development.

\section{Materials and Methods}

\subsection{Animals}

The use of animal models is essential for advancing infant nutrition knowledge because a multitude of ethical and procedural limitations preclude this research in humans. Rats are often preferred for postnatal nutrition research because regular handling of pups is comparatively well-tolerated [42,43]. The use of rats for studying outcomes of postnatal iron supplementation is also reinforced by evidence that mechanisms of iron homeostasis across stages of development are consistent between rats and humans [26-28].

Animal procedures for this study were approved by the University of California Davis Institutional Animal Care and Use Committee. Sprague Dawley rats between 8 and 10 weeks of age were obtained from Charles River Laboratories (Wilmington, MA, USA) and maintained on standard 18\% protein rodent chow (200 mg Fe/kg diet; 2018, Teklad Diets, Madison, WI, USA) in clear polycarbonate hanging cages at constant temperature 
$\left(22^{\circ} \mathrm{C}\right)$ and humidity $(63 \%)$ with standard $12 \mathrm{~h}$ light cycles; these conditions applied during habituation, breeding, and throughout the entire postnatal experimental period. Rats were habituated to the vivarium for one week prior to breeding. There were 11 nulliparous female breeders and 9 of them had litters, all of which were used for the experiment. Original litter sizes ranged between 10 to 15 pups. In order to normalize growth between litters, newborn pups born within the same $24 \mathrm{~h}$ period were randomly assigned to sexmatched litters of 10 pups. All litters nursed freely throughout the experiment, except for a brief period during daily supplementation. On postnatal day (PD) 2, litters were randomly assigned to supplementation groups ( $n=3$ litters, 10 pups each) to receive $10 \%$ sucrose vehicle control (CON) or iron as either ferrous sulfate heptahydrate (Cat\#215422-250G, Sigma-Aldrich, St. Louis, MO, USA) or ferrous bis-glycinate chelate (Albion Minerals Ferrochel ${ }^{\circledR}$, Balchem Inc., New Hampton, NY, USA). Littermates were assigned to the same treatment group to avoid coprophagic iron transfer across treatment groups, which would be highly confounding.

Pups were weighed every other day beginning PD 2, and litter average body weight (BW) was used to calculate the supplement volume, which provided $10 \mathrm{mg} \mathrm{Fe} / \mathrm{kg} \mathrm{BW}$. day. This experimental iron dose for postnatal supplementation was designed to represent the daily iron intake of an exclusively formula-fed infant, after adjusting for known differences in milk iron and iron absorption efficiency between humans and rats. References and calculations for iron dose determination are shown in Table 1 and Equation (1) (below). Iron supplements were prepared in acid-washed glassware by dissolving FS or FC in sterile $10 \% \mathrm{w} / \mathrm{v}$ sucrose at $6 \mathrm{mg}$ iron/mL. Supplementation was performed by hand-pipetting, at the same time each day from PD 2 through PD 14. To deliver calculated volume, a sterile pipette was placed gently on the roof of the mouth to stimulate natural suckling, and solution was dispensed slowly, allowing swallowing at intervals. On PD 15, pups were fasted for $6 \mathrm{~h}$ and euthanized by cardiac venipuncture under deep anesthesia (100 $\mathrm{mg}$ ketamine $\times 10 \mathrm{mg}$ xylazine $/ \mathrm{kg}$ BW). Hippocampi were dissected immediately from fresh brains and all hippocampi were dissected by the same researcher for consistency.

$$
\text { Rat Pup Supplementation Dose }=\mathrm{RM} \cdot(\mathrm{IF} / \mathrm{HM})=[6.4-14] \approx 10 \mathrm{mg} \text { iron } / \mathrm{kg} \mathrm{BW}
$$

Table 1. The daily rat pup iron supplementation dose — $10 \mathrm{mg}$ elemental iron per $\mathrm{kg}$ body weight (BW) —-was determined by estimating Adjusted Daily Iron Intakes of human milk (HM), iron-fortified formula (IF), and rat milk (RM) diets; these values were then used to calculate a daily supplemental iron intake for nursing rat pups that is proportional to the Adjusted Daily Iron Intake in infants fed exclusively IF relative to HM-fed infants (Equation (1)). Recommended iron intakes and experimental iron overload doses for adult rats are included for comparison and reference.

\begin{tabular}{|c|c|c|c|c|c|c|}
\hline Species & Diet & Diet Intake & $\begin{array}{l}\text { Dietary Iron } \\
\quad(\mathrm{ppm})\end{array}$ & $\begin{array}{c}\text { Daily Iron } \\
\text { Intake }^{1} \\
\text { (mg/kg BW) }\end{array}$ & $\begin{array}{c}\text { Iron } \\
\text { Absorption (\%) }\end{array}$ & $\begin{array}{l}\text { Adjusted Daily } \\
\text { IronIntake }{ }^{2} \\
(\mathrm{mg} / \mathrm{kg} \mathrm{BW})\end{array}$ \\
\hline Human & $\begin{array}{l}\text { Human milk } \\
\text { (HM) }\end{array}$ & $600-800 \mathrm{~mL}$ [6] & 0.35 [44] & $0.04-0.07$ & 50 [27] & $0.02-0.035$ \\
\hline Human & $\begin{array}{l}\text { Iron-Fortified } \\
\text { Formula } \\
\text { (IF) }\end{array}$ & 600-800 mL [6] & $12[7]$ & 1.4 & $10[28]$ & 0.14 \\
\hline Rat (pup) & $\begin{array}{l}\text { Rat Milk } \\
\text { (RM) }\end{array}$ & 4-10 mL [45] & $5[46]$ & $1.6-2.0$ & $100[30]$ & $1.6-2.0$ \\
\hline Rat (adult) & Standard Chow & $25-30 \mathrm{~g}$ [47] & $35-250$ [48] & $3.5-21$ & 100 [49] & $3.5-21$ \\
\hline Rat (adult) & Iron Overload & $25-30 \mathrm{~g}$ [47] & $\begin{array}{c}8000-10,000 \\
{[50,51]}\end{array}$ & $800-2500$ & NA & NA \\
\hline
\end{tabular}

\footnotetext{
${ }^{1}$ Estimations based on 5-7 kg infant; 10-30 g rat pup; 250-300 g adult rat. BW = Body Weight. ${ }^{2}$ Values have been adjusted for
} iron absorption. 


\subsection{Blood Measurements}

Whole blood ( $n=20$ per group) was collected in EDTA tubes (Safe-T-Fill Capillary Blood Collection Systems, RAM Scientific, Nashville, TN), and blood measurements were performed on the day of collection. Hemoglobin was measured by the cyanmethemoglobin method using a commercially available kit (Cat\#MAK115-1KT, Sigma-Aldrich, St. Louis, MO, USA). For hematocrit measurement, whole blood $(n=20)$ was collected in heparinized capillary tubes (Fisher Scientific, Pittsburgh, PA, USA), centrifuged, and measured in a hematocrit reader.

\subsection{Tissue Iron, Zinc, Copper, and Manganese}

Tissues (liver, $n=12$ per group; whole brains, $n=12$ per group) were flash frozen at time of collection and stored at $-20^{\circ} \mathrm{C}$. Sample weights were recorded prior to digestion in $\mathrm{HNO}_{3}(16 \mathrm{~mol} / \mathrm{L})$ at room temperature for $7 \mathrm{~d}$. The $\mathrm{HNO}_{3}$ was evaporated at sub-boiling temperatures for 6-8 h [52], and remaining tissue ash was rehydrated with ultrapure water (Milli-Q ${ }^{\circledR}$, Millipore Sigma, Burlington, MA, USA) for quantification of iron, zinc, copper, and manganese by atomic absorption spectrometry (Model Smith-Heifjie 4000, Thermo Jarrell Ash Corporation, Franklin, MA, USA).

\subsection{Histology}

At the time of collection, liver tissue ( $n=6$ per group) and whole brains ( $n=6$ per group) were immersion-fixed in $4 \% w / v$ PFA at $4{ }^{\circ} \mathrm{C}$ for $24 \mathrm{~h}$. Tissues were then washed in $1 \times$ PBS three times, stored in $70 \%$ ethanol at $4{ }^{\circ} \mathrm{C}$, and submitted to the UC Davis School of Veterinary Medicine Anatomic Pathology Laboratory for embedding by standard protocols. Tissue sections were stained for iron by Perls' Prussian blue method with nuclear fast red counterstain.

\subsection{Real-Time PCR}

Tissue samples (liver, $n=7$ per group; hippocampus, $n=7$ per group) were stored in RNAlater ${ }^{\circledR}$ (Sigma-Aldrich, St.Louis, MO, USA) solution at time of collection, kept at $4{ }^{\circ} \mathrm{C}$ for $24 \mathrm{~h}$, and then stored at $-20^{\circ} \mathrm{C}$ until extraction by the TRIzol ${ }^{\mathrm{TM}}$ protocol (Invitrogen ${ }^{\mathrm{TM}}$, Carlsbad, CA, USA). RNA was reverse transcribed to cDNA using a High-Capacity cDNA Reverse Transcription Kit with RNase Inhibitor (Cat\#4374966, Applied Biosystems ${ }^{\mathrm{TM}}$, Foster City, CA, USA) as outlined by the manufacturer. RT-PCR reactions were performed using a CFX96 Real-Time PCR System (Cat\#1725121, Bio-Rad, Hercules, CA, USA) with iTaq Universal SYBR ${ }^{\circledR}$ Green Supermix to determine relative expression of target transcripts. The fold change in target gene expression was calculated and normalized to $A c t b$ expression using the $2^{\Delta \Delta \mathrm{Ct}}$ method. Primer sequences for target and housekeeping genes are listed in Table 2.

Table 2. Real-time PCR primer sequences.

\begin{tabular}{|c|c|c|}
\hline Gene & Primer Sequence & Reference \\
\hline Actb & $\begin{array}{c}\text { F: GAAATCGTGCGTGACATTAAAGAG } \\
\text { R: GCGGCAGTGGCCATCTC }\end{array}$ & [53] \\
\hline Натр & $\begin{array}{c}\text { F: GCTGCCTGTCTCCTGCTTCT } \\
\text { R: CTGCAGAGCCGTAGTCTGTCTCGTC }\end{array}$ & [29] \\
\hline$T f$ & $\begin{array}{l}\text { F: GCATCAGACTCCAGCATCAA } \\
\text { R: CAGGACAGTCTGGTGCTTCA }\end{array}$ & [54] \\
\hline TfR1 & $\begin{array}{l}\text { F: GAGTTCACTGACATCATCAA } \\
\text { R: GCAATCCAGATGACTGAGAT }\end{array}$ & [53] \\
\hline Mag & $\begin{array}{l}\text { F: TGTGTAGCTGAGAAGGAGTATGG } \\
\text { R: ACAGTGCGATTCCAGAAGGATTAT }\end{array}$ & [55] \\
\hline$M b p$ & $\begin{array}{l}\text { F: CTCTGGCAAGGACTCACACAC } \\
\text { R: TCTGCTGAGGGACAGGCCTCTC }\end{array}$ & [56] \\
\hline$P l p$ & $\begin{array}{l}\text { F: GTGTTCTCCCATGGAATGCT } \\
\text { R: TGAAGGTGAGCAGGGAAACT }\end{array}$ & [57] \\
\hline
\end{tabular}




\subsection{Western Blotting}

Tissues (duodenum, $n=4$ per group; hippocampus, $n=6$ per group) were flash frozen in liquid nitrogen immediately after collection and stored at $-80^{\circ} \mathrm{C}$. Frozen tissue samples were homogenized by bead beating with $5 \mathrm{~mm}$ stainless steel beads (Qiagen, Valencia, CA, USA) in Pierce ${ }^{\circledR}$ RIPA Buffer (Cat\#PI89900, Thermo Fisher Scientific ${ }^{\mathrm{TM}}$, Waltham, MA, USA) with Roche cOmplete ${ }^{\mathrm{TM}}$ protease inhibitor cocktail (Cat\#NC0969110, SigmaAldrich, St. Louis, MO, USA) in a TissueLyser II (Qiagen, Valencia, CA, USA). Following quantification of tissue lysate protein by the Bradford assay, 30 ug protein samples diluted in Laemmli buffer were loaded onto 10\% TGX Stain-Free ${ }^{\mathrm{TM}}$ polyacrylamide gels (BioRad, Hercules, CA, USA) and separated by electrophoresis under reducing conditions (5\% 2-mercaptoethanol). Protein was transferred to nitrocellulose membranes using a Trans-Blot Turbo Transfer System (Bio-Rad). Stain-Free ${ }^{\mathrm{TM}}$ blot images were captured using a ChemiDoc MP (Bio-Rad, Hercules, CA, USA) and membranes were blocked with 5\% non-fat milk (Sigma-Aldrich, St. Louis, MO, USA) in $0.1 \%$ Tween ${ }^{\circledR} 20$ PBS (PBST) buffer for $1 \mathrm{~h}$. Blots were washed in PBST and resuspended in primary antibody solution for overnight incubation at $4{ }^{\circ} \mathrm{C}$. Primary antibody solutions were prepared according to the following ratios: rabbit 1:1000 rabbit anti-4-HNE (Cat\#ab46545; Abcam, Cambridge, MA, USA), 1:1000 rabbit anti-Slc40a1 (Cat\#ab58695; Abcam, Cambridge, MA, USA), and 1:100 mouse anti-Fth1 (Cat\#sc-376594; Santa Cruz Biotechnologies, Santa Cruz, CA, USA). Following overnight incubation blots were washed thoroughly with PBST and then treated with horseradish peroxidase-conjugated secondary antibody (1:5000 anti-rabbit or antimouse, Sigma-Aldrich, St. Louis, MO, USA) in blocking solution. After a final wash in PBST, SuperSignal ${ }^{\mathrm{TM}}$ West Femto Maximum Sensitivity Substrate (Thermo Scientific, Fisher Scientific ${ }^{\mathrm{TM}}$, Waltham, MA, USA) was used for chemiluminescent detection of Slc40a1 and 4HNE protein bands and ECL Plus Reagent (Thermo Scientific, Fisher Scientific ${ }^{\mathrm{TM}}$, Waltham, MA, USA) was used for detection of Fth1. Blot images were captured on the ChemiDoc ${ }^{\mathrm{TM}}$ MP (Bio-Rad, Hercules, CA, USA). Total adjusted band densities of target proteins were analyzed by Image Lab Software (Bio-Rad, Hercules, CA, USA) and normalized to total lane protein using Stain-Free ${ }^{\mathrm{TM}}$ blot images [58-60].

\subsection{Protein Carbonyl Content}

Protein carbonyl content was quantified in hippocampi ( $n=6$ per group) using an OxiSelect ${ }^{\mathrm{TM}}$ Protein Carbonyl ELISA kit (Cat\#STA-310; Cell Biolabs, Inc., San Diego, CA, USA) according to the manufacturer's instructions.

\subsection{Statistical Analysis}

Data were analyzed and plotted in GraphPad Prism (Version 8). A repeated-measures two-way ANOVA with Geisser-Greenhouse correction was used to test for treatment group effect on body weight across the supplementation period. Litters were analyzed as biological replicates, with respective pups as technical replicates when testing for effects on growth. Significant differences in gene and protein expression with treatment were detected with a one-way ANOVA with post hoc Tukey's test. The Shapiro-Wilk test was used to check for normality, and Kruskal-Wallis tests were used with Dunn's multiple comparison's test to detect group differences in nonparametric data. Individual data points representing biological replicates are plotted with the mean \pm SEM, except for growth data, where, for clarity purposes, only the mean $\pm \mathrm{SD}$ was plotted. Significance was determined at $p \leq 0.05$.

\section{Results}

\subsection{Iron Status}

We provided daily ferrous sulfate (FS) or ferrous bis-glycinate chelate (FC) iron supplements to rat pups from postnatal day (PD) 2-14 to investigate outcomes of postnatal iron supplementation. Supplements were delivered based on $10 \mathrm{mg}$ iron $/ \mathrm{kg}$ body weight (BW), a dose we designed to represent the estimated routine iron intake of an infant fed exclu- 
sively iron-fortified infant formula (Table 1 and Equation (1)). We interrogated hemoglobin and hepatic iron pools to evaluate body iron stores at PD 15 following supplementation. Initially, we tested whether differences in liver iron, hemoglobin, and hematocrit may be due to sex. We did not detect any effects on these metrics due to sex, so this variable was dropped when testing for differences among iron supplementation groups. Hemoglobin and hematocrit were 15\% higher in iron-supplemented pups (FS and FC) over CON $(p<0.0001$; Figure 1a,b). Substantial liver iron loading was also observed in all iron-supplemented pups (Figure 1c,d). Liver iron concentration following FS or FC supplementation was around $100 \times$ CON liver iron levels ( $p<0.0001$; Figure 1a), and marked ferric iron deposition blue was clearly visible with Perls' Prussian Blue iron staining in both FS and FC liver sections while nearly undetectable in CON livers (Figure 1d). No difference in hemoglobin ( $p=0.87$; Figure 1a), hematocrit $(p=0.27$; Figure 1b), or liver iron concentration $(p=0.93$; Figure 1c) was found between FS vs. FC groups $(p=0.93)$, suggesting that both iron forms elevated body iron levels similarly following daily supplementation.

(a)

(d)

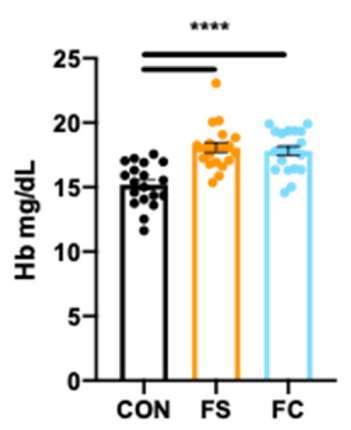

(b)

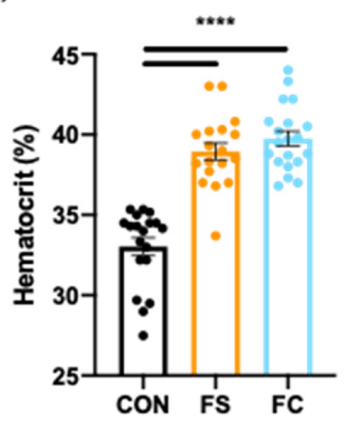

(c)

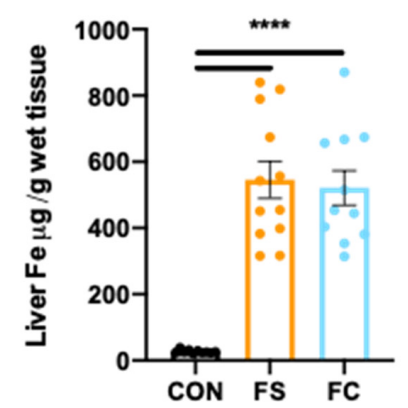

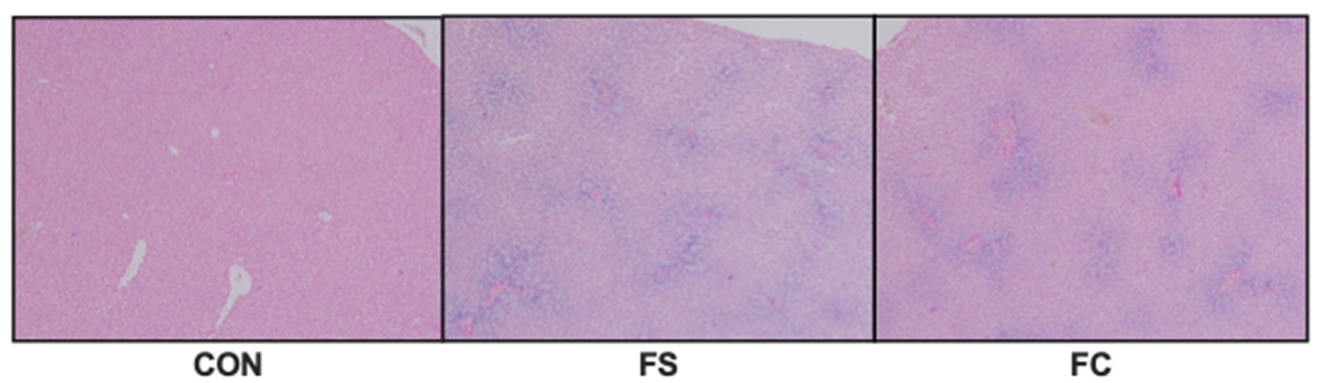

Figure 1. Iron status on postnatal day (PD) 15 following daily ferrous sulfate (FS), ferrous bis-glycinate chelate (FC), or vehicle control (CON) supplementation in rats from PD 2-14. (a) Hemoglobin and (b) hematocrit were measured from fresh whole blood ( $n=20$ /group). (c) Liver iron concentrations were quantified by atomic absorption spectrometry ( $n=12 /$ group). Values are plotted as the means \pm SEM. (d) Representative microscope images of liver sections stained with Perls' Prussian blue for the detection of ferric iron deposits were captured using a $10 \times$ objective lens $(n=6 /$ group). $p$-value summary: ****, $p<0.0001$.

\subsection{Growth and Development}

Iron supplementation can delay growth when provided to iron-sufficient infants [12-14], and therefore we recorded BW every two days across this study to investigate the influence of supplementation on growth. Litter average BW increased steadily in all litters from postnatal day (PD) 2 to PD 15 (Figure 2a) and all individual pup weights fell within normal growth curve percentiles for Sprague Dawley rats (individual values not plotted for clarity). Litter averages were analyzed as biological replicates when testing for treatment effects on BW. A repeated-measures two-way ANOVA of litter average BW detected a significant effect of time $(p<0.0001)$ but not litter group $(p=0.18)$, suggesting that postnatal BW gain was not affected by iron. 
(a)

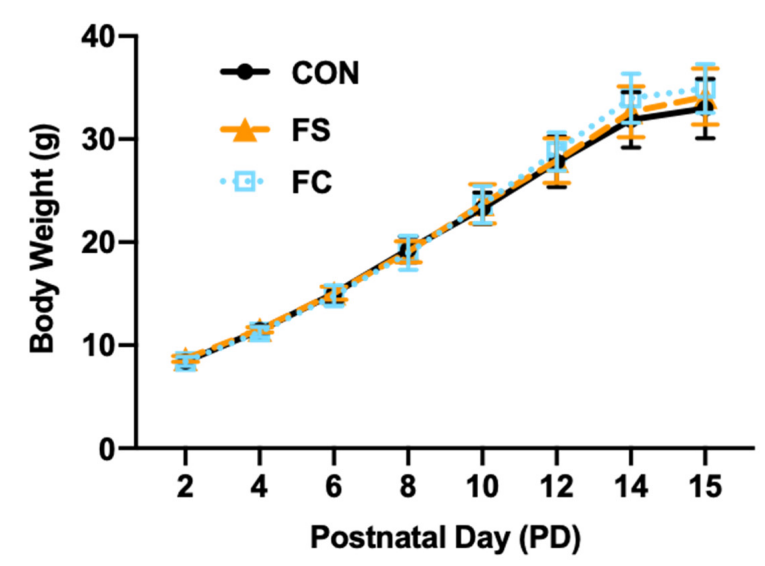

(b)

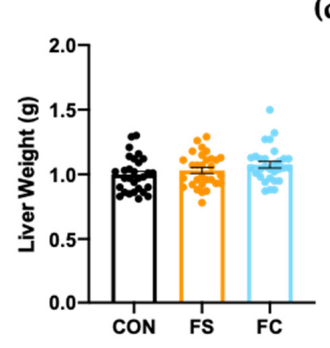

(d)

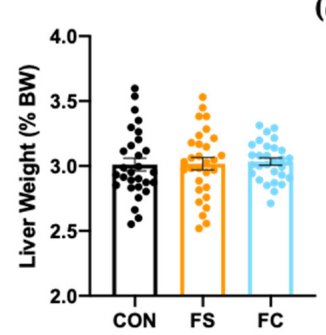

(c)

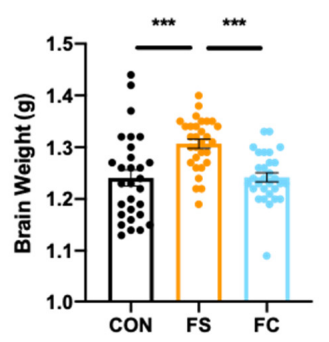

(e)

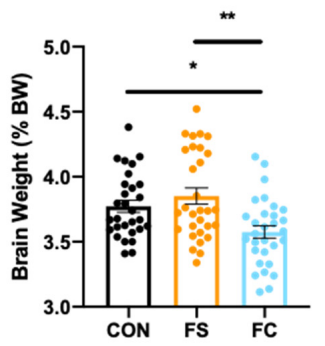

Figure 2. Weight gain and organ development with daily postnatal FS or FC supplementation in rats. (a) Pup body weights ( $n=3$ litters/group, 10 pups each litter) were recorded across the supplementation period from postnatal day (PD) 2-15; litter averages were analyzed as biological replicates and plotted as mean $\pm \mathrm{SD}$. Group and time effects were assessed by repeated-measures two-way ANOVA with Geisser-Greenhouse correction. (b) Liver and (c) brain weights were recorded at time of collection on PD 15 and normalized to body weight $(\mathbf{d}, \mathbf{e})$. Organ weight values are plotted as the means \pm SEM. $p$-value summary: ${ }^{*}, p<0.05 ;{ }^{* *}, p<0.01 ;{ }^{* * *}, p<0.001$.

Organ weights were measured on PD 15 at time of collection to detect organ toxicity effects [61]. No effect of sex on liver or brain weight was detected at this age. Treatment influenced brain weight, but results of pairwise comparisons were affected when raw brain weight values were normalized to BW. Mean FS brain weight (raw weight in g) was greater than in the FC and CON groups ( $p<0.05$; Figure $2 \mathrm{c}$ ). However, mean FS brain weight ( $\%$ $\mathrm{BW})$ was not different from $\mathrm{CON}$, and FC brain weight (\% BW) was significantly lower than both FS $(p<0.01)$ and CON ( $p<0.05$; Figure 2e). With or without normalization, FS brains were significantly heavier than FC brains. Liver weight, in contrast, was not different between groups ( $p=0.10$; Figure $2 \mathrm{~b}$ ), and this remained true when values were normalized to body weight ( $p=0.99$; Figure $2 \mathrm{~d}$ ). Overall, brain development was affected by iron supplement form and this effect does not appear to be related to iron status, since iron status was similar between the FS and FC groups (Figure 1a-d). 


\subsection{Systemic Iron Homeostasis}

When iron stores become elevated in healthy individuals, the liver releases the iron regulator hepcidin to prevent iron overload [62,63]. Hepcidin reduces dietary iron uptake by blocking activity of the iron exporter ferroportin in enterocytes $[62,64]$ and inherited disruptions to this pathway result in hemochromatosis (i.e., iron overload) [65-69]. We assessed liver hepcidin (Hamp) and duodenal ferroportin (Slc40a1) expression in rats at PD 15 to observe systemic iron homeostasis following daily postnatal iron supplementation, and to test for differences between FS and FC. Hamp was increased by at least 1000-fold in FS and FC pups $(p<0.0001$; Figure $3 a)$, but no difference was found between iron groups. We did not observe a treatment effect on duodenal Slc40a1 expression $(p=0.09$; Figure $3 b$ ), in support of findings suggesting that iron absorption is under-regulated in early life $[25,28,30,31]$. It appears that duodenal Slc40a1 trended toward increased expression with iron supplementation, but due to the small sample size ( $n=4$ per group), it is possible that our Slc40a1 analysis was underpowered to detect a significant change. Further, iron homeostasis outcomes of iron supplementation may not depend upon iron form.

(a)

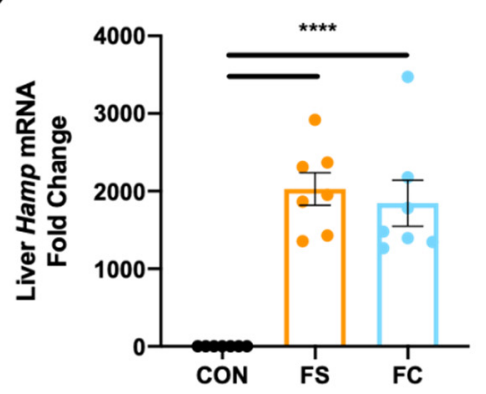

(b)

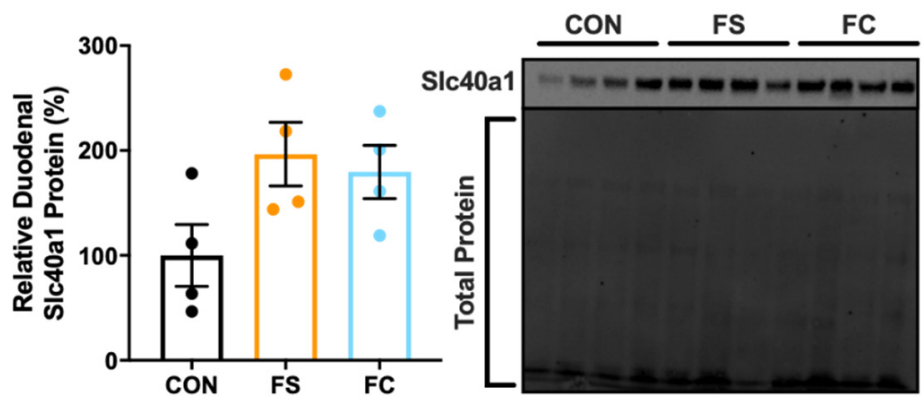

Figure 3. Changes in systemic iron regulation at PD 15. (a) Liver hepcidin (Hamp) mRNA expression was assessed by real-time PCR ( $n=7-8$ /group). Values with the mean \pm SEM are plotted as fold change relative to CON means. (b) Relative expression of the iron exporter protein, ferroportin (Slc40a1), was assessed in the proximal small intestine ( $n=4$ /group). Adjusted Slc40a1 band density was normalized to total protein with the Stain-Free ${ }^{\mathrm{TM}}$ method, and values are plotted relative to mean CON expression (\%) as the means \pm SEM. $p$-value summary: ${ }^{* * *}, p<0.0001$.

\subsection{Iron and Trace Minerals in the Central Nervous System}

Next, we measured iron levels in the CNS at PD 15 to determine whether postnatal iron supplementation led to sustained brain iron loading, but in spite of increased overall iron status this was not the case. Indeed, no difference was found in whole brain iron concentrations among groups $(p=0.91)$, suggesting that, in contrast to the liver, the CNS may be protected from iron loading following postnatal supplementation at physiological doses.

We suspected that iron supplementation might reduce availability of other trace minerals in the CNS, as iron can disrupt the metabolism of other essential trace minerals through mineral-mineral interactions $[15,20]$. To test whether availability of these minerals was altered in the CNS following postnatal iron supplementation, zinc $(\mathrm{Zn})$, copper $(\mathrm{Cu})$, and manganese $(\mathrm{Mn})$ concentrations were also quantified in whole brains. Congruent with brain iron results, brain zinc $(p=0.28)$, manganese $(p=0.84)$, and copper $(p=0.34)$ concentrations were unaffected by iron supplementation at this age.

\subsection{Iron Regulation in the Hippocampus}

Iron must be tightly regulated in the CNS to sustain basic cellular functions, neurotransmitter synthesis, and myelination. The hippocampus-a CNS region known for its central role in learning and memory-is considered highly sensitive to changes in iron availability during early development and aging. Hippocampal iron deficiency (ID) can permanently disrupt cognitive development, while hippocampal overload is a key component in Alzheimer's Disease pathophysiology. We assessed iron loading and iron 
regulation in the hippocampus at PD 15 to observe whether the hippocampus had sustained iron loading following postnatal iron supplementation. Ferric iron deposits were undetectable in hippocampal sections (representative slides shown in Figure 4a), and no effect on hippocampal ferritin heavy chain protein (Fth1) expression was observed ( $p=0.07$; Figure $4 \mathrm{c}$ ). This suggests iron loading did not occur in the hippocampus following iron supplementation, because iron is stored in ferritin and its components are upregulated in response to increased iron [70-72]. In addition to storing iron as Ft, the CNS can prevent iron overload during increased iron status by downregulating transferrin-bound iron uptake by transferrin receptor (Tfr1) or by increasing iron export via Slc40a1; transferrin is also upregulated in the CNS to quench free iron molecules during cellular iron overload or oxidative stress $[54,73,74]$. We found no differences in Tfr $1(p=0.42$; Figure $4 b)$ or Tf ( $p=0.27$; Figure $4 \mathrm{~d})$ mRNA expression among groups, nor did we observe changes in Slc40a1 protein ( $p=0.24$; Figure 4e). Taken together, these data do not indicate sustained iron loading had occurred in the hippocampus following postnatal iron supplementation.

(a)

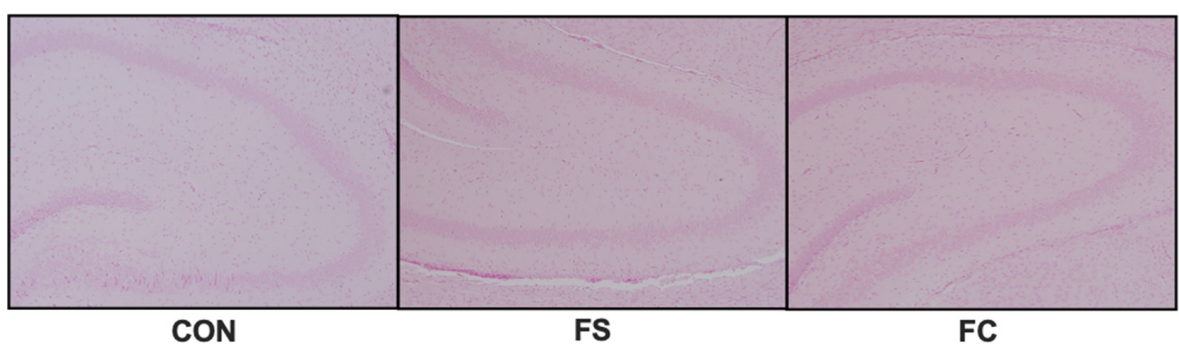

(b)

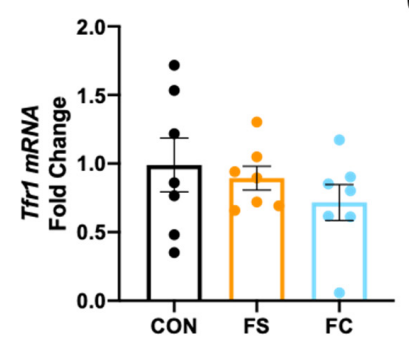

(d)

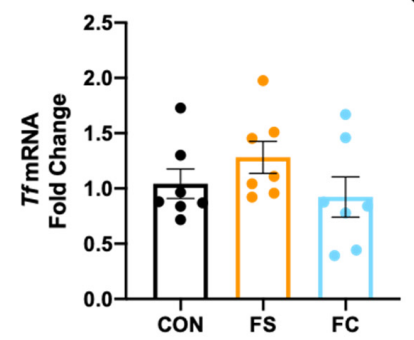

(c)
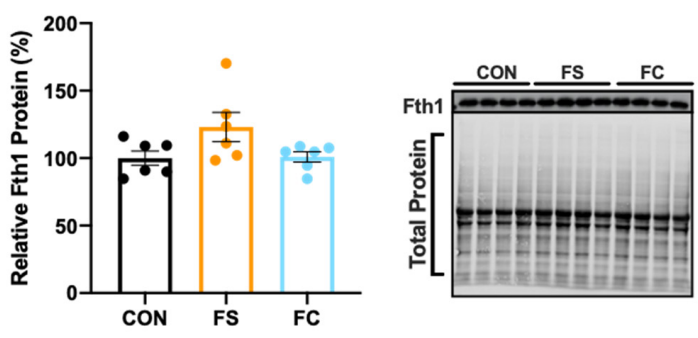

(e)

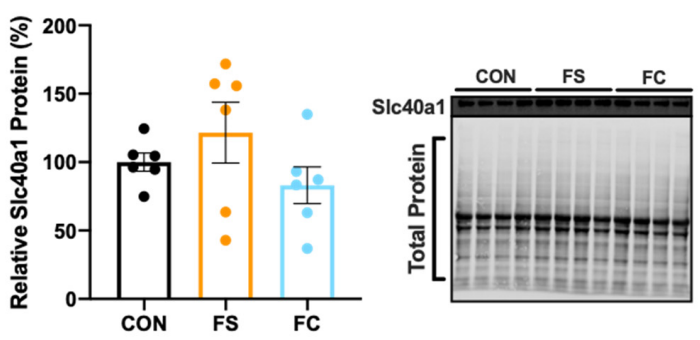

Figure 4. Hippocampal iron loading and regulation on PD 15. (a) Representative microscope images of hippocampal sections stained with Perls' Prussian blue stain for ferric iron detection, captured with 10x objective lens ( $n=5-6 /$ group). (b) Transferrin receptor (Tfr1) and (d) transferrin (Tf) mRNA expression in hippocampal tissue, shown as fold change relative to CON $(n=$ 7/group). (c) Hippocampal expression of ferritin heavy chain (Fth1) subunit, and (e) iron exporter protein ferroportin (Slc40a1) expression were normalized to total protein using the Stain-Free ${ }^{\mathrm{TM}}$ method and plotted relative $(\%)$ to CON expression $(n=$ 6 /group). Representative blots shown on the right with total protein. Values are shown as the means \pm SEM.

\subsection{Oxidative Stress in the Hippocampus}

Iron induces oxidative damage in the CNS, including the hippocampus, and this may cause neurodegeneration [32], so we reasoned that postnatal iron supplementation might elevate oxidative stress in the hippocampus even in the absence of sustained iron loading effects, as this may occur through transient increases in CNS iron undetected by our study 
design. Hippocampal oxidative stress was quantified by measuring 4-hydroxynonenal (4HNE), a known product of lipid peroxidation [75]. The quantity of $4 \mathrm{HNE}$ modified proteins, assessed by Western blot, did not differ among groups ( $p=0.54$; Figure $5 \mathrm{a})$; however, a slight effect on protein carbonyl content, a stable byproduct of protein oxidation, was observed [76]. Less oxidized protein was detected in the hippocampus of FS pups compared to the other groups, suggesting reduced hippocampal oxidative stress in this group ( $p=0.04$; Figure $5 b)$.

(a)

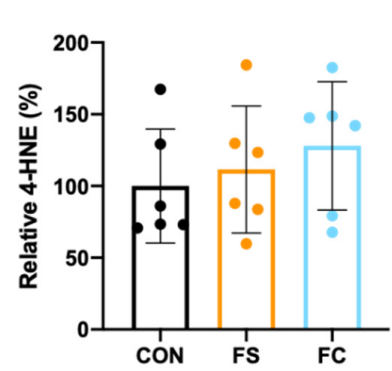

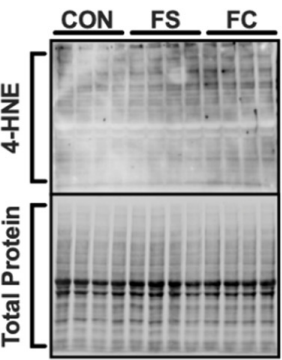

(b)

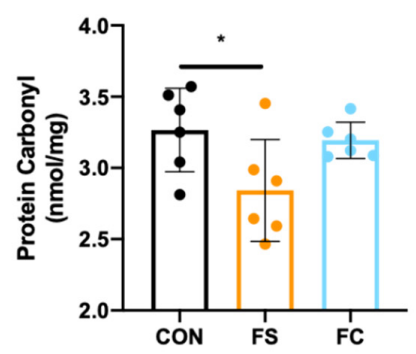

Figure 5. Hippocampal oxidative stress at PD 15. (a) To detect lipid peroxidation effects, 4-hydroxynonenal (4HNE)

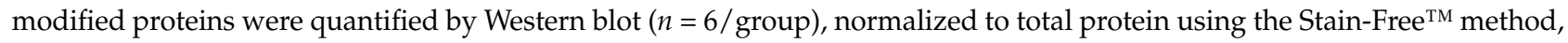
and values with the mean \pm SEM are plotted relative to mean CON expression (\%). A representative blot with Stain-Free ${ }^{\mathrm{TM}}$ total protein blot is shown to the right. (b) Protein carbonyl content, a marker of protein oxidation, was quantified in hippocampal tissue lysates by enzyme-linked immunosorbent assay (ELISA; $n=6$ /group). Values are plotted as the means \pm SEM. $p$-value summary: ${ }^{*}, p<0.05$.

\subsection{Myelination in the Hippocampus}

Myelination occurs mainly during postnatal development in rats and synthesis of myelin peaks beginning PD 14 until PD 34 [77]. Iron accumulation causes oxidative stress and cell death in oligodendrocytes, which myelinate neurons in the CNS [78]. In piglets, iron supplementation reduced hippocampal myelination gene expression [38]. We sought to determine if hippocampal myelination was impacted by daily postnatal iron supplementation in rats, so we measured expression of several major myelin genes in the hippocampus, including Mag, Mbp, and Plp (Figure 6). Myelin associated glycoprotein (Mag) signals myelin and axonal formation, while myelin basic protein (Mbp) and proteolipid protein (Plp) play major structural roles in myelination [79]. We found no difference in expression of Mag, Mbp, or Plp mRNA in the hippocampus at PD 15, suggesting that myelination was not impacted by either iron supplement $(p=0.69$; Figure 6$)$.

(a)

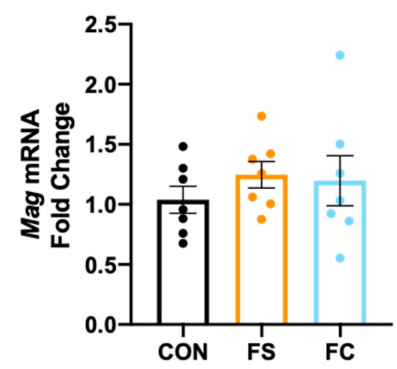

(b)

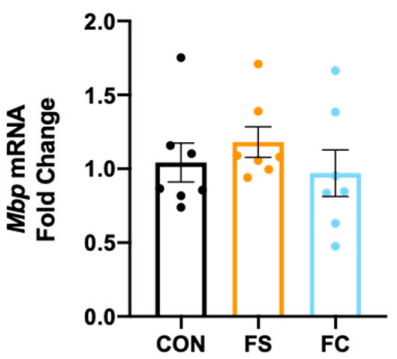

(c)

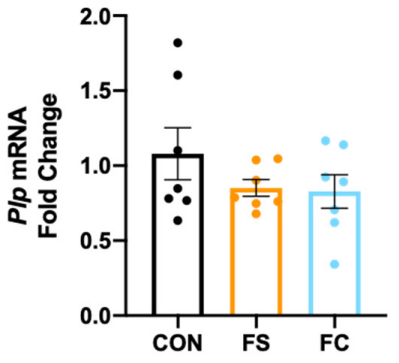

Figure 6. Hippocampal myelination gene expression at PD 15. Expression of major myelin components, (a) myelinassociated glycoprotein (Mag), (b) myelin basic protein $(\mathrm{Mbp})$, and (c) myelin proteolipid protein (Plp) as assessed in hippocampal tissue by real-time PCR ( $n=7$ /group). Values are plotted as fold change relative to CON as the means \pm SEM. 


\section{Discussion}

Ferrous sulfate (FS) supplementation and formula fortification prevent postnatal iron deficiency (ID) $[4,6]$, but may be harmful to iron-replete infants $[15,18,20]$. Excess iron intake through high-iron formula or iron drops can lead to growth delays, and adverse cognitive and behavioral outcomes [9-11,19]. Infants may be especially susceptible to these adverse effects, because under-regulation of iron in early life permits excessive iron absorption and this may lead to iron loading in the developing central nervous system (CNS) [8,25,31]. Adverse neurodevelopment outcomes [23-25] and oxidative stress of the CNS $[25,38]$ have been observed in animals supplemented with iron postnatally. Research on the effects of postnatal iron supplementation in healthy subjects is limited and existing animal studies have often not been designed to mimic routine iron administration. We developed a translationally-optimized iron supplementation experiment in rat pups (Table 1 and Equation (1)) to compare effects of ferrous bis-glycinate chelate (FC) or ferrous sulfate (FS) on development, systemic iron regulation, CNS trace mineral content, and hippocampus-specific markers of iron regulation, oxidative stress, and myelination.

First, we characterized iron status following supplementation with FS or FC. Hemoglobin, hematocrit, and liver iron content were all substantially increased in iron-supplemented pups at PD 15 (Figure 1). Liver iron concentration is more sensitive and specific to excess body iron loading than blood indices for iron status. Excess body iron is taken up by the liver for storage, and in turn, the liver controls body iron homeostasis to prevent overload. Before being assigned to treatment groups on PD 2, litters were culled to age-matched litters of 10, a normal litter size for Sprague Dawley rats. Therefore, it can be assumed that $\mathrm{CON}$ pups received sufficient dietary iron via milk feeding and should not have required additional iron. Yet, we observed large effects on hemoglobin, hematocrit, and liver iron content when pups were supplemented with iron, and this is probably due to under-regulation of iron absorption (Figure 3). When liver iron increases, the liver makes hepcidin, the iron systemic iron regulator that downregulates intestinal iron absorption by blocking the iron exporter, ferroportin (Slc40a1) [20-22]. Infant iron absorption was previously reported to be unaffected by dose, mode of delivery, or infant iron status [27,80], and in previous experiments in rodents [29-31] and piglets [25] intestinal ferroportin was hypo-responsive to hepcidin following iron supplementation. One study investigating this early life phenomenon in rats concluded that hypo-responsiveness of ferroportin protein to hepcidin during suckling may be explained by elevated iron-regulatory element (IRE+) Slc40a1 transcripts, which allow for upregulation of Slc40a1 in response to elevated enterocyte iron levels [29]. That study demonstrated that weanling and adult rats mainly express an Slc40a1 transcript variant lacking IRE (IRE-) in the duodenum. Expression of IRE-Slc40a1 in weanling and adult rats allows enterocytes to avoid translational regulation by iron regulatory proteins (IRPs); enterocyte Slc40a1 protein is primarily controlled by hepcidin after weaning. However, in pre-weanling pups expressing higher levels of IRE+ Slc40a1 transcripts, translation of Slc40a1 is upregulated in response to iron; Slc40a1 remains elevated even in the presence of elevated hepcidin levels. The authors concluded that elevated IRE+ Slc40a1 during suckling may help to maximize the supply of iron during a critical period of increased iron demands [29]. In our study, liver iron concentrations in FS and FC pups were 100x control (CON) levels (Figure 1c), and liver hepcidin expression was 1000-fold CON expression, but we found no change in intestinal ferroportin protein (Figure 3). Indeed, there was a trend toward increased ferroportin expression (Figure $3 \mathrm{~b}$ ); however, our duodenal Western blot analysis may have been underpowered to detect a significant increase. Therefore, our results are consistent with previous findings that infants receiving iron through iron supplements or iron-fortified formula absorb iron unmitigatedly and may be at increased risk for iron overload. Both FS and FC supplementation comparably increased iron levels, hemoglobin, hematocrit (Figure 1), and similar liver Hamp expression and duodenal ferroportin protein expression was detected between FS and FC groups (Figure 3). Indeed, neither iron status nor iron 
homeostasis outcomes were affected by iron form; both forms elevated body iron stores to levels far beyond that of CON pups.

Iron deficiency and iron toxicity are both harmful, and both inhibit growth and proliferation of cells [81]. A limited number of studies have investigated whether postnatal iron supplementation benefits long-term growth and development [18,82-84]. Iron supplementation of iron-sufficient infants might delay growth but this is not consistent $[9,12,14,82,83,85]$. We observed no effect of iron supplementation on litter weight gain (Figure 2a), suggesting that neither FS nor FC iron affects short-term weight gain in early life when provided at routine levels. Similar findings have been reported in previous animals studies, which have used both lower and higher daily doses of FS: in pre-weanling pigs-where the same daily dose of FS was used (10 mg iron/ $\mathrm{kg} \mathrm{BW}$ ) from PD2-21—weight gain was not affected, nor was weight gain affected with $50 \mathrm{mg}$ iron/ $\mathrm{kg}$ BW [25], and BW was not affected in pre-weaning rats following supplementation with either 30 or $150 \mu \mathrm{g}$ iron per day [30]. In these studies, increasing the dose of iron increased iron status but did not change growth. Thus, our results are consistent with previous experiments in animals. We also analyzed liver and brain weights following iron supplementation in rats, because organ weight is often measured to detect neonatal toxicity in rodent models [61]. Liver size typically decreases with exposure to environmental toxins [86]. We observed no difference in liver weight following iron supplementation, indicating an absence of toxic effects in the liver (Figure 2b,d). Nevertheless, brain weight was affected depending on iron form (Figure 2c,e). Data are shown as brain weight and brain \% BW because current research has not determined which is more meaningful in terms of postnatal neurodevelopment [61]. In both analyses (Figure 2c,e), FS brains were heavier than FC brains. Therefore, we conclude that brain weight effects following postnatal iron supplementation are dependent upon the form of iron. Additional studies with more specific indicators of neurodevelopment are needed to determine whether functional differences may arise related to brain weight or iron source.

Previous studies have observed iron loading in the CNS following iron supplementation $[25,30]$ and this may also alter availability of other trace metals through iron-mineral interactions $[15,20]$. We reasoned that differences in brain size between the iron forms might be explained by differences in iron loading or trace metal availability between FS and FC groups, but neither iron, zinc, copper, nor manganese levels were different between these groups in our study. Regarding the negative cognitive and behavioral outcomes that were observed in infants given iron-fortified formula, these results suggest dietary iron intake from iron-fortified formula is unlikely to have caused sustained brain iron loading or disruptions to zinc, copper, or manganese availability in the CNS. Furthermore, these findings do not support the hypothesis that long-term cognitive outcomes of postnatal iron supplementation are due to direct effects of iron loading or iron-mineral interactions in the CNS. Neither does it appear likely that sustained iron loading nor changes in iron regulation had occurred specifically in the hippocampus, as we had suspected it would (Figure 4). Postnatal CNS iron loading might happen transiently, or after exceptionally high oral doses are used as previously reported $[25,30]$. Considering that brain trace minerals were not altered and considering that overall iron status was similar between FS and FC groups, it is unclear how FS brains became heavier than FC brains. These results provide novel evidence that iron form might influence neurodevelopment outcomes of iron supplementation.

Iron loading causes oxidative stress in the brain and this appears to be a central mechanism in neurodegenerative pathologies [32,33]. Oxidative stress has also been observed in the CNS following neonatal iron exposure [87]. Iron loading initiates pro-oxidative reactions in cells and this can be toxic to the CNS $[78,88,89]$. Recently in piglets, iron supplementation at $50 \mathrm{mg}$ iron/ $\mathrm{kg}$ BW as FS from PD 2 to PD 21 increased hippocampal lipid peroxidation compared to $10 \mathrm{mg}$ iron $/ \mathrm{kg}$ and control groups, but this was not statistically significant [25]. In the present experiment, we used $10 \mathrm{mg}$ iron $/ \mathrm{kg}$ BW. No change in hippocampal lipid peroxidation was observed, and only borderline less hippocampal 
protein oxidation was seen in the FS group, suggesting that neither iron treatment induced hippocampal oxidative stress (Figure 5). Protein oxidation was not different among the iron groups in the hippocampus, so we further conclude that differences in brain size cannot be explained by differences in oxidative stress outcomes between iron forms. Congruent to both these and the CNS mineral loading results, we also did not detect changes in myelination gene expression (Figure 6).

There are inherent limitations to extending the findings of this study to all healthy, iron-sufficient infants in spite of our optimization efforts. We believe that $10 \mathrm{mg}$ iron $/ \mathrm{kg}$ BW is representative of the iron intake of iron-fortified formula-fed infants, but dietary iron intake may vary widely in healthy infants. It is possible that many infants may be exposed to significantly more iron (e.g., preterm infants) or less iron (mixed-fed infants) than the average formula-fed infant. It is likely that significantly increasing or decreasing the dose used in our study would lead to different iron status and development outcomes. Future studies should define the dose-response relationship between postnatal iron intake, iron status, growth, and neurodevelopment at this stage of life.

In conclusion, specific development effects of postnatal iron supplementation at routine levels may not be clearly related to iron status effects and instead dependent upon indirect mechanisms related to iron form. The long-term functional consequences of these effects remain to be elucidated. The differential effects on brain growth between FS- and FC-supplemented pups provides evidence that iron impacts postnatal development in a form dependent manner. Additional studies in this area are warranted to optimize dose, timing, and form of iron for infants such that any negative health outcomes are identified and prevented without compromising risk for iron deficiency.

Author Contributions: Conceptualization, S.M. and B.L.; investigation, S.M.; writing-original draft preparation, S.M.; writing-review and editing, B.L.; supervision, B.L.; funding acquisition, S.M. and B.L. All authors have read and agreed to the published version of the manuscript.

Funding: This research was funded by Albion ${ }^{\circledR}$ Minerals and Balchem ${ }^{\circledR}$ Corporation.

Institutional Review Board Statement: Animal experiments were reviewed and approved on 4 October 2017 by the Institutional Animal Care and Use Committee (IACUC) at University of California, Davis, under the Protocol for Animal Care and Use \#20171.

Data Availability Statement: The data presented in this study are not publicly available. The data are available on request from the corresponding author.

Acknowledgments: We thank Eric B. Nonnecke, for assisting with animal necropsy, data interpretation, and manuscript review. We also thank Xiaogu Du, for assisting with animal necropsy, and we thank undergraduate researchers Ayah Awaad, Sophia Cheung, Emily Liang, and Momna Shahbaz for assisting with animal experiments and laboratory analyses.

Conflicts of Interest: The funders had no role in the design of the study; in the collection, analyses, or interpretation of data; in the writing of the manuscript, or in the decision to publish the results.

\section{References}

1. Black, R.E.; Heidkamp, R. Causes of Stunting and Preventive Dietary Interventions in Pregnancy and Early Childhood. In Nestlé Nutrition Institute Workshop Series; Colombo, J., Koletzko, B., Lampl, M., Eds.; S. Karger AG: Basel, Switzerland, 2018; Volume 89, pp. 105-113. ISBN 978-3-318-06351-6. [CrossRef]

2. McCann, J.C.; Ames, B.N. An Overview of Evidence for a Causal Relation between Iron Deficiency during Development and Deficits in Cognitive or Behavioral Function. Am. J. Clin. Nutr. 2007, 85, 931-945. [CrossRef]

3. Baker, R.D.; Greer, F.R. The Committee on Nutrition Diagnosis and Prevention of Iron Deficiency and Iron-Deficiency Anemia in Infants and Young Children (0-3 Years of Age). Pediatrics 2010, 126, 1040-1050. [CrossRef]

4. Guideline: Daily Iron Supplementation in Infants and Children; WHO Guidelines Approved by the Guidelines Review Committee; World Health Organization: Geneva, Switzerland, 2016; ISBN 978-92-4-154952-3.

5. Pasricha, S.-R.; Drakesmith, H.; Black, J.; Hipgrave, D.; Biggs, B.-A. Control of Iron Deficiency Anemia in Low- and Middle-Income Countries. Blood 2013, 121, 2607-2617. [CrossRef]

6. Shelov, S.P.; American Academy of Pediatrics. Caring for Your Baby and Young Child: Birth to Age Five; Bantam: New York, NY, USA, 2009; ISBN 978-0-553-38630-1. 
7. Lönnerdal, B.O.; Keen, C.L.; Ohtake, M.; Tamura, T. Iron, Zinc, Copper, and Manganese in Infant Formulas. Am. J. Dis. Children 1983, 137, 433-437. [CrossRef]

8. Lönnerdal, B. Development of Iron Homeostasis in Infants and Young Children. Am. J. Clin. Nutr. 2017, 106, 1575S-1580S. [CrossRef]

9. Dewey, K.G.; Domellöf, M.; Cohen, R.J.; Landa Rivera, L.; Hernell, O.; Lönnerdal, B. Iron Supplementation Affects Growth and Morbidity of Breast-Fed Infants: Results of a Randomized Trial in Sweden and Honduras. J. Nutr. 2002, 132, $3249-3255$. [CrossRef] [PubMed]

10. Lozoff, B. Iron-Fortified vs Low-Iron Infant Formula: Developmental Outcome at 10 Years. Arch. Pediatr. Adolesc. Med. 2012, 166, 208. [CrossRef] [PubMed]

11. Gahagan, S.; Delker, E.; Blanco, E.; Burrows, R.; Lozoff, B. Randomized Controlled Trial of Iron-Fortified versus Low-Iron Infant Formula: Developmental Outcomes at 16 Years. J. Pediatr. 2019, 212, 124-130.e1. [CrossRef] [PubMed]

12. Lind, T.; Seswandhana, R.; Persson, L.-Å.; Lönnerdal, B. Iron Supplementation of Iron-Replete Indonesian Infants Is Associated with Reduced Weight-for-Age. Acta Paediatr. Oslo Nor. 1992 2008, 97, 770-775. [CrossRef] [PubMed]

13. Idjradinata, P.; Watkins, W.E.; Pollitt, E. Adverse Effect of Iron Supplementation on Weight Gain of Iron-Replete Young Children. Lancet Lond. Engl. 1994, 343, 1252-1254. [CrossRef]

14. Majumdar, I.; Paul, P.; Talib, V.H.; Ranga, S. The Effect of Iron Therapy on the Growth of Iron-Replete and Iron-Deplete Children. J. Trop. Pediatr. 2003, 49, 84-88. [CrossRef]

15. Lonnerdal, B. Excess Iron Intake as a Factor in Growth, Infections, and Development of Infants and Young Children. Am. J. Clin. Nutr. 2017, 106, 1681S-1687S. [CrossRef]

16. Hare, D.J.; Arora, M.; Jenkins, N.L.; Finkelstein, D.I.; Doble, P.A.; Bush, A.I. Is Early-Life Iron Exposure Critical in Neurodegeneration? Nat. Rev. Neurol. 2015, 11, 536-544. [CrossRef]

17. Hare, D.J.; Cardoso, B.R.; Szymlek-Gay, E.A.; Biggs, B.-A. Neurological Effects of Iron Supplementation in Infancy: Finding the Balance between Health and Harm in Iron-Replete Infants. Lancet Child Adolesc. Health 2018, 2, 144-156. [CrossRef]

18. Hare, D.J.; Braat, S.; Cardoso, B.R.; Morgan, C.; Szymlek-Gay, E.A.; Biggs, B.-A. Health Outcomes of Iron Supplementation and/or Food Fortification in Iron-Replete Children Aged 4-24 Months: Protocol for a Systematic Review and Meta-Analysis. Syst. Rev. 2019, 8, 253. [CrossRef]

19. Agrawal, S.; Berggren, K.L.; Marks, E.; Fox, J.H. Impact of High Iron Intake on Cognition and Neurodegeneration in Humans and in Animal Models: A Systematic Review. Nutr. Rev. 2017, 75, 456-470. [CrossRef] [PubMed]

20. Wessling-Resnick, M. Excess Iron: Considerations Related to Development and Early Growth. Am. J. Clin. Nutr. 2017, 106, 1600S-1605S. [CrossRef] [PubMed]

21. Georgieff, M.K.; Krebs, N.F.; Cusick, S.E. The Benefits and Risks of Iron Supplementation in Pregnancy and Childhood. Annu. Rev. Nutr. 2019, 39, 121-146. [CrossRef]

22. Dietary Guidelines Advisory Committee. Scientific Report of the 2020 Dietary Guidelines Advisory Committee: Advisory Report to the Secretary of Agriculture and the Secretary of Health and Human Services; U.S. Department of Agriculture, Agricultural Research Service: Washington, DC, USA, 2020; p. 786.

23. Alexeev, E.E.; He, X.; Slupsky, C.M.; Lönnerdal, B. Effects of Iron Supplementation on Growth, Gut Microbiota, Metabolomics and Cognitive Development of Rat Pups. PLoS ONE 2017, 12, e0179713. [CrossRef] [PubMed]

24. Fredriksson, A.; Schröder, N.; Eriksson, P.; Izquierdo, I.; Archer, T. Neonatal Iron Exposure Induces Neurobehavioural Dysfunctions in Adult Mice. Toxicol. Appl. Pharmacol. 1999, 159, 25-30. [CrossRef] [PubMed]

25. Ji, P.; Lönnerdal, B.; Kim, K.; Jinno, C.N. Iron Oversupplementation Causes Hippocampal Iron Overloading and Impairs Social Novelty Recognition in Nursing Piglets. J. Nutr. 2019, 149, 398-405. [CrossRef]

26. Fredriksson, A.; Schröder, N.; Eriksson, P.; Izquierdo, I.; Archer, T. Neonatal Iron Potentiates Adult MPTP-Induced Neurodegenerative and Functional Deficits. Parkinsonism Relat. Disord. 2001, 7, 97-105. [CrossRef]

27. Domellöf, M.; Lönnerdal, B.; Abrams, S.A.; Hernell, O. Iron Absorption in Breast-Fed Infants: Effects of Age, Iron Status, Iron Supplements, and Complementary Foods. Am. J. Clin. Nutr. 2002, 76, 198-204. [CrossRef]

28. Lönnerdal, B.; Georgieff, M.K.; Hernell, O. Developmental Physiology of Iron Absorption, Homeostasis, and Metabolism in the Healthy Term Infant. J. Pediatr. 2015, 167, S8-S14. [CrossRef] [PubMed]

29. Darshan, D.; Wilkins, S.J.; Frazer, D.M.; Anderson, G.J. Reduced Expression of Ferroportin-1 Mediates Hyporesponsiveness of Suckling Rats to Stimuli That Reduce Iron Absorption. Gastroenterology 2011, 141, 300-309. [CrossRef] [PubMed]

30. Leong, W.-I.; Bowlus, C.L.; Tallkvist, J.; Lönnerdal, B. Iron Supplementation during Infancy-Effects on Expression of Iron Transporters, Iron Absorption, and Iron Utilization in Rat Pups. Am. J. Clin. Nutr. 2003, 78, 1203-1211. [CrossRef] [PubMed]

31. Frazer, D.M.; Wilkins, S.J.; Darshan, D.; Mirciov, C.S.G.; Dunn, L.A.; Anderson, G.J. Ferroportin Is Essential for Iron Absorption During Suckling, But Is Hyporesponsive to the Regulatory Hormone Hepcidin. Cell. Mol. Gastroenterol. Hepatol. $2017,3,410-421$. [CrossRef]

32. Li, J.; Cao, F.; Yin, H.; Huang, Z.; Lin, Z.; Mao, N.; Sun, B.; Wang, G. Ferroptosis: Past, Present and Future. Cell Death Dis. 2020, 11, 88. [CrossRef]

33. Carocci, A.; Catalano, A.; Sinicropi, M.S.; Genchi, G. Oxidative Stress and Neurodegeneration: The Involvement of Iron. Biometals Int. J. Role Met. Ions Biol. Biochem. Med. 2018, 31, 715-735. [CrossRef] [PubMed] 
34. Nuñez, M.T.; Chana-Cuevas, P. New Perspectives in Iron Chelation Therapy for the Treatment of Neurodegenerative Diseases. Pharmaceuticals 2018, 11, 109. [CrossRef] [PubMed]

35. Dornelles, A.S.; Garcia, V.A.; de Lima, M.N.M.; Vedana, G.; Alcalde, L.A.; Bogo, M.R.; Schröder, N. MRNA Expression of Proteins Involved in Iron Homeostasis in Brain Regions Is Altered by Age and by Iron Overloading in the Neonatal Period. Neurochem. Res. 2010, 35, 564-571. [CrossRef] [PubMed]

36. Fernandez, L.L.; de Lima, M.N.M.; Scalco, F.; Vedana, G.; Miwa, C.; Hilbig, A.; Vianna, M.; Schröder, N. Early Post-Natal Iron Administration Induces Astroglial Response in the Brain of Adult and Aged Rats. Neurotox. Res. 2011, 20, 193-199. [CrossRef] [PubMed]

37. Fernandez, L.L.; Carmona, M.; Portero-Otin, M.; Naudi, A.; Pamplona, R.; Schröder, N.; Ferrer, I. Effects of Increased Iron Intake during the Neonatal Period on the Brain of Adult AbetaPP/PS1 Transgenic Mice. J. Alzheimers Dis. JAD 2010, 19, 1069-1080. [CrossRef]

38. Ji, P.; Nonnecke, E.B.; Doan, N.; Lönnerdal, B.; Tan, B. Excess Iron Enhances Purine Catabolism Through Activation of Xanthine Oxidase and Impairs Myelination in the Hippocampus of Nursing Piglets. J. Nutr. 2019, 149, 1911-1919. [CrossRef]

39. Figueiredo, L.S.; de Freitas, B.S.; Garcia, V.A.; Dargél, V.A.; Köbe, L.M.; Kist, L.W.; Bogo, M.R.; Schröder, N. Iron Loading Selectively Increases Hippocampal Levels of Ubiquitinated Proteins and Impairs Hippocampus-Dependent Memory. Mol. Neurobiol. 2016, 53, 6228-6239. [CrossRef]

40. Hertrampf, E.; Olivares, M. Iron Amino Acid Chelates. Int. J. Vitam. Nutr. Res. 2004, 74, 435-443. [CrossRef] [PubMed]

41. Pineda, O.; Ashmead, H.D. Effectiveness of Treatment of Iron-Deficiency Anemia in Infants and Young Children with Ferrous Bis-Glycinate Chelate. Nutrition 2001, 17, 381-384. [CrossRef]

42. Puiman, P.; Stoll, B. Animal Models to Study Neonatal Nutrition in Humans. Curr. Opin. Clin. Nutr. Metab. Care 2008, 11, 601-606. [CrossRef]

43. Pérez-Cano, F.J.; Franch, À.; Castellote, C.; Castell, M. The Suckling Rat as a Model for Immunonutrition Studies in Early Life. Clin. Dev. Immunol. 2012, 2012, 1-16. [CrossRef]

44. Domellöf, M.; Lönnerdal, B.; Dewey, K.G.; Cohen, R.J.; Hernell, O. Iron, Zinc, and Copper Concentrations in Breast Milk Are Independent of Maternal Mineral Status. Am. J. Clin. Nutr. 2004, 79, 111-115. [CrossRef]

45. Fiorotto, M.L.; Burrin, D.G.; Perez, M.; Reeds, P.J. Intake and Use of Milk Nutrients by Rat Pups Suckled in Small, Medium, or Large Litters. Am. J. Physiol.-Regul. Integr. Comp. Physiol. 1991, 260, R1104-R1113. [CrossRef] [PubMed]

46. Keen, C.L.; Lönnerdal, B.; Clegg, M.; Hurley, L.S. Developmental Changes in Composition of Rat Milk: Trace Elements, Minerals, Protein, Carbohydrate and Fat. J. Nutr. 1981, 111, 226-236. [CrossRef] [PubMed]

47. Křǐžova, E.; Imek, V.S.; Abelenda, M.; Puerta, M. Food Intake and Body Weight in Rats with Daily Food-Availability Restrictions. Physiol. Behav. 1996, 60, 791-794. [CrossRef]

48. National Research Council (US) Subcommittee on Laboratory Animal Nutrition. Nutrient Requirements of the Laboratory Rat. In Nutrient Requirements of Laboratory Animals, 4th ed.; National Academies Press (US): Washington, DC, USA, $1995 ;$ p. 32.

49. Swain, J.H.; Newman, S.M.; Hunt, J.R. Bioavailability of Elemental Iron Powders to Rats Is Less than Bakery-Grade Ferrous Sulfate and Predicted by Iron Solubility and Particle Surface Area. J. Nutr. 2003, 133, 3546-3552. [CrossRef]

50. Atarashi, M.; Izawa, T.; Mori, M.; Inai, Y.; Kuwamura, M.; Yamate, J. Dietary Iron Overload Abrogates Chemically-Induced Liver Cirrhosis in Rats. Nutrients 2018, 10, 1400. [CrossRef]

51. Mori, M.; Izawa, T.; Inai, Y.; Fujiwara, S.; Aikawa, R.; Kuwamura, M.; Yamate, J. Dietary Iron Overload Differentially Modulates Chemically-Induced Liver Injury in Rats. Nutrients 2020, 12, 2784. [CrossRef]

52. Clegg, M.S.; Keen, C.L.; Lönnerdal, B.; Hurley, L.S. Influence of Ashing Techniques on the Analysis of Trace Elements in Animal Tissue: I. Wet Ashing. Biol. Trace Elem. Res. 1981, 3, 107-115. [CrossRef]

53. Li, Y.; Yu, P.; Chang, S.-Y.; Wu, Q.; Yu, P.; Xie, C.; Wu, W.; Zhao, B.; Gao, G.; Chang, Y.-Z. Hypobaric Hypoxia Regulates Brain Iron Homeostasis in Rats. J. Cell. Biochem. 2017, 118, 1596-1605. [CrossRef] [PubMed]

54. Yang, W.M.; Jung, K.J.; Lee, M.O.; Lee, Y.S.; Lee, Y.H.; Nakagawa, S.; Niwa, M.; Cho, S.S.; Kim, D.W. Transient Expression of Iron Transport Proteins in the Capillary of the Developing Rat Brain. Cell. Mol. Neurobiol. 2011, 31, 93-99. [CrossRef]

55. Ghiani, C.A.; Ying, Z.; de Vellis, J.; Gomez-Pinilla, F. Exercise Decreases Myelin-Associated Glycoprotein Expression in the Spinal Cord and Positively Modulates Neuronal Growth. Glia 2007, 55, 966-975. [CrossRef]

56. Paintlia, M.K.; Paintlia, A.S.; Barbosa, E.; Singh, I.; Singh, A.K. N-Acetylcysteine Prevents Endotoxin-Induced Degeneration of Oligodendrocyte Progenitors and Hypomyelination in Developing Rat Brain. J. Neurosci. Res. 2004, 78, 347-361. [CrossRef]

57. Ueno, T.; Ito, J.; Hoshikawa, S.; Ohori, Y.; Fujiwara, S.; Yamamoto, S.; Ohtsuka, T.; Kageyama, R.; Akai, M.; Nakamura, K.; et al. The Identification of Transcriptional Targets of Ascl1 in Oligodendrocyte Development. Glia 2012, 60, 1495-1505. [CrossRef]

58. Dittmer, A.; Dittmer, J. $\beta$-Actin Is Not a Reliable Loading Control in Western Blot Analysis. Electrophoresis 2006, 27, 2844-2845. [CrossRef] [PubMed]

59. Gilda, J.E.; Gomes, A.V. Stain-Free Total Protein Staining Is a Superior Loading Control to $\beta$-Actin for Western Blots. Anal. Biochem. 2013, 440, 186-188. [CrossRef]

60. Colella, A.D.; Chegenii, N.; Tea, M.N.; Gibbins, I.L.; Williams, K.A.; Chataway, T.K. Comparison of Stain-Free Gels with Traditional Immunoblot Loading Control Methodology. Anal. Biochem. 2012, 430, 108-110. [CrossRef] [PubMed]

61. Bailey, S.A.; Zidell, R.H.; Perry, R.W. Relationships Between Organ Weight and Body/Brain Weight in the Rat: What Is the Best Analytical Endpoint? Toxicol. Pathol. 2004, 32, 448-466. [CrossRef] [PubMed] 
62. Nemeth, E. Hepcidin Regulates Cellular Iron Efflux by Binding to Ferroportin and Inducing Its Internalization. Science 2004, 306, 2090-2093. [CrossRef]

63. Muckenthaler, M.U.; Rivella, S.; Hentze, M.W.; Galy, B. A Red Carpet for Iron Metabolism. Cell 2017, 168, 344-361. [CrossRef]

64. Billesbølle, C.B.; Azumaya, C.M.; Kretsch, R.C.; Powers, A.S.; Gonen, S.; Schneider, S.; Arvedson, T.; Dror, R.O.; Cheng, Y.; Manglik, A. Structure of Hepcidin-Bound Ferroportin Reveals Iron Homeostatic Mechanisms. Nature 2020, 586, 807-811. [CrossRef]

65. Chiu, M.K.; Davey, A.M. Neonatal Hemochromatosis. Clin. Pediatr. (Phila.) 1997, 36, 607-610. [CrossRef]

66. Corradini, E.; Buzzetti, E.; Pietrangelo, A. Genetic Iron Overload Disorders. Mol. Asp. Med. 2020, 75, 100896. [CrossRef]

67. Joshi, R.; Shvartsman, M.; Morán, E.; Lois, S.; Aranda, J.; Barqué, A.; Cruz, X.; Bruguera, M.; Vagace, J.M.; Gervasini, G.; et al. Functional Consequences of Transferrin Receptor-2 Mutations Causing Hereditary Hemochromatosis Type 3. Mol. Genet. Genom. Med. 2015, 3, 221-232. [CrossRef] [PubMed]

68. Yun, S.; Vincelette, N.D. Update on Iron Metabolism and Molecular Perspective of Common Genetic and Acquired Disorder, Hemochromatosis. Crit. Rev. Oncol. Hematol. 2015, 95, 12-25. [CrossRef]

69. Bardou-Jacquet, E.; Brissot, P. Diagnostic Evaluation of Hereditary Hemochromatosis (HFE and Non-HFE). Hematol. Oncol. Clin. N. Am. 2014, 28, 625-635. [CrossRef] [PubMed]

70. Kajarabille, N.; Latunde-Dada, G.O. Programmed Cell-Death by Ferroptosis: Antioxidants as Mitigators. Int. J. Mol. Sci. 2019, 20, 4968. [CrossRef] [PubMed]

71. Focht, S.J.; Snyder, B.S.; Beard, J.L.; Van Gelder, W.; Williams, L.R.; Connor, J.R. Regional Distribution of Iron, Transferrin, Ferritin, and Oxidatively-Modified Proteins in Young and Aged Fischer 344 Rat Brains. Neuroscience 1997, 79, 255-261. [CrossRef]

72. Erikson, K.M.; Pinero, D.J.; Connor, J.R.; Beard, J.L. Regional Brain Iron, Ferritin and Transferrin Concentrations during Iron Deficiency and Iron Repletion in Developing Rats. J. Nutr. 1997, 127, 2030-2038. [CrossRef] [PubMed]

73. Bradbury, M.W. Transport of Iron in the Blood-Brain-Cerebrospinal Fluid System. J. Neurochem. 1997, 69, 443-454. [CrossRef]

74. Siddappa, A.J.M.; Rao, R.B.; Wobken, J.D.; Leibold, E.A.; Connor, J.R.; Georgieff, M.K. Developmental Changes in the Expression of Iron Regulatory Proteins and Iron Transport Proteins in the Perinatal Rat Brain. J. Neurosci. Res. 2002, 68, 761-775. [CrossRef]

75. Houglum, K.; Filip, M.; Witztum, J.L.; Chojkier, M. Malondialdehyde and 4-Hydroxynonenal Protein Adducts in Plasma and Liver of Rats with Iron Overload. J. Clin. Investig. 1990, 86, 1991-1998. [CrossRef] [PubMed]

76. Stadtman, E.R. Metal Ion-Catalyzed Oxidation of Proteins: Biochemical Mechanism and Biological Consequences. Free Radic. Biol. Med. 1990, 9, 315-325. [CrossRef]

77. Downes, N.; Mullins, P. The Development of Myelin in the Brain of the Juvenile Rat. Toxicol. Pathol. 2014, 42, 913-922. [CrossRef]

78. Roth, A.D.; Núñez, M.T. Oligodendrocytes: Functioning in a Delicate Balance Between High Metabolic Requirements and Oxidative Damage. In Glial Cells in Health and Disease of the CNS; von Bernhardi, R., Ed.; Advances in Experimental Medicine and Biology; Springer International Publishing: Cham, Switzerland, 2016; Volume 949, pp. 167-181. ISBN 978-3-319-40762-3.

79. Stassart, R.M.; Möbius, W.; Nave, K.-A.; Edgar, J.M. The Axon-Myelin Unit in Development and Degenerative Disease. Front. Neurosci. 2018, 12, 467. [CrossRef]

80. Szymlek-Gay, E.A.; Domellöf, M.; Hernell, O.; Hurrell, R.F.; Lind, T.; Lönnerdal, B.; Zeder, C.; Egli, I.M. Mode of Oral Iron Administration and the Amount of Iron Habitually Consumed Do Not Affect Iron Absorption, Systemic Iron Utilisation or Zinc Absorption in Iron-Sufficient Infants: A Randomised Trial. Br. J. Nutr. 2016, 116, 1046-1060. [CrossRef] [PubMed]

81. Camaschella, C.; Nai, A.; Silvestri, L. Iron Metabolism and Iron Disorders Revisited in the Hepcidin Era. Haematologica 2020, 105, 260-272. [CrossRef] [PubMed]

82. Pasricha, S.-R.; Hayes, E.; Kalumba, K.; Biggs, B.-A. Effect of Daily Iron Supplementation on Health in Children Aged 4-23 Months: A Systematic Review and Meta-Analysis of Randomised Controlled Trials. Lancet Glob. Health 2013, 1, e77-e86. [CrossRef]

83. Petry, N.; Olofin, I.; Boy, E.; Donahue Angel, M.; Rohner, F. The Effect of Low Dose Iron and Zinc Intake on Child Micronutrient Status and Development during the First 1000 Days of Life: A Systematic Review and Meta-Analysis. Nutrients 2016, 8, 773. [CrossRef] [PubMed]

84. Lozoff, B.; Beard, J.; Connor, J.; Barbara, F.; Georgieff, M.; Schallert, T. Long-Lasting Neural and Behavioral Effects of Iron Deficiency in Infancy. Nutr. Rev. 2006, 64, S34-S43. [CrossRef] [PubMed]

85. Gahagan, S.; Yu, S.; Kaciroti, N.; Castillo, M.; Lozoff, B. Linear and Ponderal Growth Trajectories in Well-Nourished, Iron-Sufficient Infants Are Unimpaired by Iron Supplementation. J. Nutr. 2009, 139, 2106-2112. [CrossRef] [PubMed]

86. Uemitsu, N.; Nishimura, C.; Nakayoshi, H. Evaluation of Liver Weight Changes Following Repeated Administration of Carbon Tetrachloride in Rats and Body-Liver Weight Relationship. Toxicology 1986, 40, 181-190. [CrossRef]

87. Berggren, K.L.; Chen, J.; Fox, J.; Miller, J.; Dodds, L.; Dugas, B.; Vargas, L.; Lothian, A.; McAllum, E.; Volitakis, I.; et al. Neonatal Iron Supplementation Potentiates Oxidative Stress, Energetic Dysfunction and Neurodegeneration in the R6/2 Mouse Model of Huntington's Disease. Redox Biol. 2015, 4, 363-374. [CrossRef] [PubMed]

88. Miwa, C.P.; de Lima, M.N.M.; Scalco, F.; Vedana, G.; Mattos, R.; Fernandez, L.L.; Hilbig, A.; Schröder, N.; Vianna, M.R.M. Neonatal Iron Treatment Increases Apoptotic Markers in Hippocampal and Cortical Areas of Adult Rats. Neurotox. Res. 2011, 19, 527-535. [CrossRef] [PubMed]

89. Rathnasamy, G.; Murugan, M.; Ling, E.-A.; Kaur, C. Hypoxia-Induced Iron Accumulation in Oligodendrocytes Mediates Apoptosis by Eliciting Endoplasmic Reticulum Stress. Mol. Neurobiol. 2016, 53, 4713-4727. [CrossRef] 